F. Yilmaz, S. B. Tosun*

\title{
EVALUATION OF SAFETY TRENDS IN CONSTRUCTION, MINING AND TRANSPORTATION SECTORS IN TURKEY
}

UDK 331.45:614.8](560)

RECEIVED: 2017-03-06

ACCEPTED: $2017-10-20$

\begin{abstract}
SUMMARY: Production processes in construction, mining and transportation involves high risks of occupational accidents all over the world. In 2014, 25.6\% of the total accidents and $65 \%$ of fatal accidents occured in these three sectors in Turkey. According to the Eurostat data, in 2014, $20 \%$ of all work-related accidents and $38 \%$ of fatal accidents have occurred in these sectors in EU. The fatality rates in Turkey are very high compared to EU countries. In Turkey, these sectors have high accident risks due to its production processes, use of low-tech, negative conditions and labor-intensive characteristics. Production machines are old, and protective-preventive services are inadequate. Especially in the construction sector, unregistered labor and subcontracting is widespread. Labor inspection is inadequate. In EU accession process, legislative works done in the field of health and safety in Turkey in recent years have not been enough. New regulations were introduced related to protective-preventive services, risk assessment, information and education workers. Nevertheless, occupational accidents has not decreased at the desired level. This paper contains a comperative and statistical analysis of accidents in coal mining, construction and transportation sectors in Turkey and EU. The official statistics data are used in the EU and Turkey. To prevent accidents, action plans must be prepared for each of the three sectors. Practices must be determined and followed strictly within the frame of these action plans
\end{abstract}

Key words: accidents, accident prevention, public health, safety, Turkey

\section{INTRODUCTION}

According to the Turkish Social Security Institute, more than 200 thousand occupational accidents occured in Turkey in 2014 and 2015. As a result of these accidents, totally 3000 workers died and 5000 workers became permanently incapable. Occupational accidents and safety in Turkey, one of the most important problem areas for many years.

*Assist. Prof. Dr. Fatih Yilmaz, (ftyilmaz@yildiz.edu.tr), Yildiz Technical University, Faculty of Mechanical, Department of Industrial Engineering, Safety Programme, Besiktas, Istanbul, Turkey, Assist. Prof. Dr. Serpil Bardakci Tosun, (serpil.bardakci@alanya.edu.tr), Alanya Alaaddin Keykubat University, Faculty of Business Administration, Department of Human Resources Management, Turkey.
Production processes in some industries such as construction, metal manufacturing, mining and transportation involves high risks of occupational accidents all over the world. As a result of these accidents, thousands of workers are injured or died each year in Turkey. In 2014, 25.6\% of the total work-related accidents, $65 \%$ of total fatal accidents have occurred in these three sectors in Turkey. As in all developing countries, these sectors have high accident risks due to its production processes, use of low-tech, negative conditions and labor-intensive characteristics. Legislative works done in the field of occupational health and safety in Turkey in recent years have not been enough. However, occupational accidents occurring in these industries have 
been significantly reduced in developed countries and also EU countries.

Accident incidence rates and fatality incidence rates are important indicators to perform statistical evaluations and comparisons related to safety and health. Occupational accident incidence rates and accident fatality rates are calculated and published by Eurostat annually. However, the official sectoral accident incidence rates and fatal accident incidence rates are not calculated and published in Turkey. Accident incidence rates show the trends of accidents in a country. It also allows for estimation and analysis of accidents and comparison by other country and sectors.

The aim of this study is to evaluate the trends of fatal and non-fatal occupational injuries in Turkey by using epidemiologic criterias. The paper aims is to investigate and calculate occupational accidents and incidence rates of fatal and non-fatal accidents in Coal Mining, Construction and Transportation sectors which the most fatal accidents occurring in Turkey. This paper is also aims to comparison the accident and fatality incidence rates with EU countries. Basic reasons of accidents, preventive measures and recommendations are also presented.

\section{MATERIAL AND METHOD}

The data that is used in the study is prepared by using the official occupational accident statistics taken from Turkish Social Security Institution and Eurostat. Tables are prepared from sectoral contribution of the recorded official insured workers, accident numbers, accident incidence rates and fatality incidence rates. Occupational accident and fatality incidence rates in coal mining, construction and transportation sectors are also calculated on the basis of years for Turkey. All collected data is used to make comments on the data.

Occupational Accident Incidence Rate =

Fatal Occupational Accident Incidence Rate =
Occupational accident incidence rates and accident fatality rates are calculated and published by Eurostat for EU annually. However, the official sectoral accident incidence rates and fatal accident incidence rates are not calculated and published in Turkey. Therefore, accident incidence rates and fatality incidence rates have been calculated for coal mining, construction and transportation sectors for Turkey and compared with the EU statistics in this paper.

The incidence rate is used in many social sciences, particularly in epidemiology. Incidence in epidemiology is a measure of the probability of occurrence of a given medical condition in a population within a specified period of time. Although sometimes loosely expressed simply as the number of new cases during some time period, it is better expressed as a proportion or a rate with a denominator.

Incidence rate is the number of new cases within a specified time period divided by the size of the population initially at risk. For example, if a population initially contains 1,000 non-diseased persons and 28 develop a condition over two years of observation, the incidence proportion is 28 cases per 1,000 persons per two years, i.e. $2.8 \%$. Incidence rate is specified as 1000,100 thousand or million people. The incidence rate is a calculation method of that allows to make various comparisons and analysis in medicine and social sciences. Incidence rate is also often used in health and safety issues and risk assessment processes (Last, 2001; Coggon, Rose and Barker, 1997; Dembe et al., 2005; Dunn and Clark, 2009; Turkkan and Pala, 2016).

In most of international statistical classifications and also in Eurostat statistical database, occupational incidence rate is calculated as number of occupational accidents for per 100 thousand workers. For this reason, in this paper, occupational accident incidence rates and fatal accident incidence rates in Turkey are calculated by the following formulas:

$\begin{aligned} & \text { Occupational Accident Incidence Rate }= \\ & \text { Fatal Occupational Accident Incidence Rate }= \\ & \text { Annually number of insured workers in sector } \\ & \text { Annually number of fatal accidents in sector } \\ & \text { Annumber of insured workers in sector }\end{aligned} \times 100,00$




\section{RESULTS}

\section{Severity of Accidents in Coal Mining, Construc- tion and Transportation Sectors in Turkey}

More than 200 thousand occupational accidents occured in Turkey every year in last decade and as a result of these accidents, approximately 1500 workers died and 2000-3000 workers became permanently incapable annually. Occupational accidents cause approximately $\$ 4$ billion income loss in social security system. All of occupational accidents are not recorded and many of accidents are not identified.

Mining, construction and transport sectors make a significant contribution to the economy in terms of GDP and employment in Turkey. Table 1 shows the contribution of these sectors to GDP, employment and growth rates. In recent years, there has been significant growth in these sectors in terms of income and employment. $\mathrm{Ne}$ vertheless, occupational accidents in these sectors can not be prevented despite all precautions.

Production processes in spesific sectors such as construction, metal manufacturing, mining and transportation involves high risks of occupational accidents all over the world and also Turkey. As a result of accidents, thousands of workers are injured or died each year in Turkey. Table 2 presents 3 sectors at which most fatal accidents are seen for the last 12 years in Turkey. According the last decade's data, coal mining sector, which was in the third place after metal product manufacturing and construction sectors in terms of occupational accidents until 2009, has risen to the first place in 2009-2013.

Coal still maintains its importance as a traditional energy source in developing countries and also Turkey. Coal mining has high accident risks due to its production processes, negative conditions and labor-intensive characteristics. Thus, occupational accident rates are 5-6 times more in comparison with the other sectors. Risk factors that cause the accidents in mining sector such as fire, firedamp and dust explosions, smoke inhalation, collapses, landslides, electric shocks, lifting equipments, hand tools and falling objects etc. are investigated in many previous studies (Groves, Kecojevic and Komljenovic, 2007; Pappas et al., 2003; Grayson, 2001; Hull et al., 1996).

Table 1. Contribution of the sectors to GDP, employment and growth rates

Tablica 1. Udio sektora u BDP-u, zapošljavanju i stopama rasta

\begin{tabular}{|c|c|c|c|c|c|c|c|c|c|}
\hline \multirow[b]{2}{*}{ Years } & \multicolumn{3}{|c|}{ Mining } & \multicolumn{3}{|c|}{ Construction } & \multicolumn{3}{|c|}{ Transportation } \\
\hline & GDP & Employment & $\begin{array}{c}\text { Growth } \\
\text { Rate }\end{array}$ & GDP & Employment & $\begin{array}{c}\text { Growth } \\
\text { Rate }\end{array}$ & GDP & Employment & $\begin{array}{c}\text { Growth } \\
\text { Rate }\end{array}$ \\
\hline 2009 & 1.5 & 103,000 & -6.7 & 3.8 & $1,249,000$ & -16.1 & 11.2 & $1,081,000$ & -7.8 \\
\hline 2010 & 1.4 & 115,000 & 4.7 & 4.2 & $1,431,000$ & 18.3 & 11.1 & $1,009,000$ & 11 \\
\hline 2011 & 1.5 & 125,000 & 3.9 & 4.5 & $1,676,000$ & 11.5 & 11.6 & $1,044,000$ & 10.4 \\
\hline 2012 & 1.5 & 113,000 & 0.8 & 4.4 & $1,709,000$ & 0.6 & 12 & $1,095,000$ & 2 \\
\hline 2013 & 1.4 & 105,000 & -3.4 & 4.4 & $1,782,000$ & 7.4 & 11.9 & $1,152,000$ & 3.9 \\
\hline 2014 & 1.5 & 134,000 & 5.6 & 4.6 & $1,912,000$ & 2.2 & 12 & $1,119,000$ & 2.6 \\
\hline 2015 & 1.3 & & & 4.8 & & & 12 & & \\
\hline
\end{tabular}


Table 2. Number of Non-Fatal, Fatal Accidents, Accident Incidence Rates and Fatal Accident Incidence Rates in EU Countries and Turkey (per 100000 workers)*

Tablica 2. Broj nesmrtnih nesreća, smrti, stopa učestalosti nesreća i stopa nesreća sa smrtnim ishodom u zemljama EU-a i Turskoj (na 100000 radnika)

\begin{tabular}{|c|c|c|c|c|c|c|c|c|c|c|c|c|c|}
\hline & \multicolumn{4}{|c|}{ COAL MINING } & \multicolumn{4}{|c|}{ CONSTRUCTION } & \multicolumn{4}{|c|}{ TRANSPORTATION/SHIPPING } \\
\hline & & \multirow{2}{*}{ 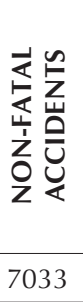 } & \multirow{2}{*}{ 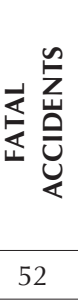 } & \multirow[t]{2}{*}{ 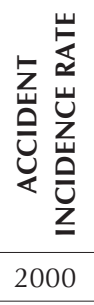 } & \multirow[t]{2}{*}{ 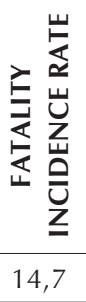 } & \multirow{2}{*}{ 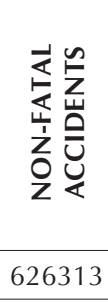 } & \multirow{2}{*}{ 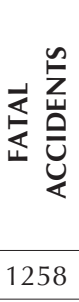 } & \multirow[t]{2}{*}{ 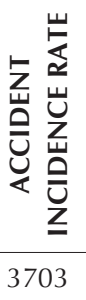 } & \multirow[t]{2}{*}{ 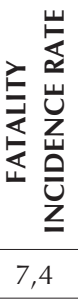 } & \multirow{2}{*}{ 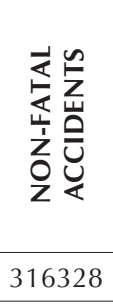 } & \multirow{2}{*}{ 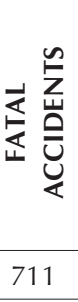 } & \multirow[t]{2}{*}{ 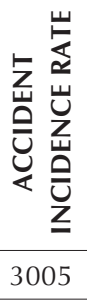 } & \multirow[t]{2}{*}{ 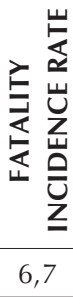 } \\
\hline \multirow{7}{*}{$\begin{array}{l}\infty \\
\stackrel{\infty}{ } \\
\supset \\
\sim\end{array}$} & 2008 & & & & & & & & & & & & \\
\hline & 2009 & 6806 & 49 & 1784 & 12,8 & 548657 & 1156 & 3447 & 7,2 & 296743 & 586 & 2813 & 5,5 \\
\hline & 2010 & 6146 & 21 & 2337 & 7,9 & 504532 & 1049 & 3214 & 6,6 & 313545 & 680 & 3004 & 6,5 \\
\hline & 2011 & 5333 & 46 & 1651 & 14,2 & 479869 & 958 & 3425 & 6,8 & 286186 & 613 & 2776 & 5,9 \\
\hline & 2012 & 4388 & 28 & 1679 & 10,7 & 418414 & 869 & 3094 & 6,6 & 268705 & 562 & 2611 & 5,4 \\
\hline & 2013 & 4367 & 27 & 1818 & 11,2 & 378261 & 787 & 2821 & 5,8 & 283586 & 549 & 2724 & 5,2 \\
\hline & 2014 & 4188 & 33 & 1940 & 15,2 & 350545 & 739 & 2698 & 5 & 256798 & 605 & 2404 & 5,6 \\
\hline \multirow{7}{*}{ 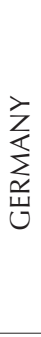 } & 2008 & 862 & 2 & 1220 & 2,8 & 125756 & 125 & 4841 & 4,8 & 70610 & 114 & 3821 & 6,1 \\
\hline & 2009 & 558 & 0 & 1197 & 0 & 127649 & 95 & 4703 & 3,5 & 65789 & 106 & 3122 & 5 \\
\hline & 2010 & 520 & 0 & 1427 & 0 & 112210 & 85 & 4159 & 3,1 & 78351 & 110 & 3569 & 5 \\
\hline & 2011 & 430 & 1 & 879 & 2 & 125306 & 112 & 5650 & 5 & 74777 & 98 & 3532 & 4,6 \\
\hline & 2012 & 272 & 2 & 606 & 4,4 & 116909 & 97 & 5192 & 4,3 & 70816 & 96 & 3286 & 4,4 \\
\hline & 2013 & 297 & 1 & 1076 & 3,6 & 105052 & 80 & 4609 & 3,5 & 73634 & 64 & 3325 & 2,8 \\
\hline & 2014 & 303 & 0 & 1234 & 0 & 114495 & 99 & 5003 & 4,3 & 65002 & 81 & 2877 & 3,5 \\
\hline \multirow{7}{*}{$\frac{z}{\frac{z}{\alpha}}$} & 2008 & 2732 & 3 & 47839 & 52,5 & 162152 & 180 & 8961 & 9,9 & 44257 & 86 & 6077 & 11,8 \\
\hline & 2009 & 2624 & 2 & 35584 & 27,1 & 104199 & 123 & 7575 & 8,9 & 36479 & 62 & 5287 & 8,9 \\
\hline & 2010 & 2256 & 1 & 33621 & 14,9 & 85513 & 100 & 6829 & 7,9 & 34565 & 70 & 4929 & 9,9 \\
\hline & 2011 & 1798 & 6 & 30249 & 100,9 & 68947 & 106 & 6754 & 10,3 & 29730 & 74 & 4459 & 11,1 \\
\hline & 2012 & 1690 & 1 & 33222 & 19,6 & 44892 & 68 & 5507 & 8,3 & 24200 & 61 & 3776 & 9,5 \\
\hline & 2013 & 1372 & 6 & 32481 & 142 & 37565 & 58 & 5389 & 8,3 & 25279 & 40 & 3915 & 6,2 \\
\hline & 2014 & 1478 & 1 & 35752 & 24,1 & 38263 & 59 & 6149 & 9,4 & 25768 & 63 & 4173 & 10,2 \\
\hline \multirow{7}{*}{$\begin{array}{l}\text { U } \\
\frac{z}{\Delta} \\
\frac{1}{4}\end{array}$} & 2008 & 2 & 0 & 0 & 0 & 109405 & 74 & 7382 & 4,9 & 57125 & 37 & 5881 & 3,8 \\
\hline & 2009 & 1 & 0 & 28 & 0 & 102320 & 133 & 5368 & 6,9 & 56123 & 87 & 4366 & 6,7 \\
\hline & 2010 & 0 & 0 & 0 & 0 & 98042 & 113 & 5430 & 6,2 & 59333 & 90 & 5906 & 8,9 \\
\hline & 2011 & 0 & 0 & 0 & 0 & 98758 & 130 & 7012 & 9,2 & 58490 & 95 & 6147 & 9,9 \\
\hline & 2012 & 0 & 0 & 0 & 0 & 92144 & 124 & 6000 & 8 & 58148 & 86 & 5685 & 8,4 \\
\hline & 2013 & 0 & 0 & 0 & 0 & 86078 & 133 & 5695 & 8,8 & 57814 & 94 & 5717 & 9,3 \\
\hline & 2014 & 0 & 0 & 0 & 0 & 82934 & 128 & 6191 & 9,5 & 57109 & 102 & 4671 & 8,3 \\
\hline
\end{tabular}




\begin{tabular}{|c|c|c|c|c|c|c|c|c|c|c|c|c|c|}
\hline \multirow{7}{*}{$\frac{⿱ 亠 乂}{\frac{1}{E}}$} & 2008 & 42 & 0 & 0 & 0 & 78155 & 184 & 3936 & 9,2 & 48659 & 116 & 4513 & 10,7 \\
\hline & 2009 & 42 & 0 & 20290 & 0 & 67288 & 184 & 3374 & 9,2 & 43310 & 85 & 3977 & 7,8 \\
\hline & 2010 & 45 & 0 & 9890 & 0 & 59620 & 183 & 3005 & 9,2 & 41188 & 101 & 3814 & 9,3 \\
\hline & 2011 & 25 & 0 & 22638 & 0 & 50364 & 143 & 2728 & 7,7 & 35361 & 48 & 3297 & 4,4 \\
\hline & 2012 & 39 & 0 & 21320 & 0 & 39865 & 110 & 2273 & 6,2 & 30046 & 57 & 2821 & 5,3 \\
\hline & 2013 & 34 & 0 & 10827 & 0 & 37762 & 101 & 2373 & 6,3 & 32306 & 59 & 3092 & 5,6 \\
\hline & 2014 & 23 & 0 & 6653 & 0 & 33005 & 105 & 2224 & 7 & 30237 & 59 & 2910 & 5,6 \\
\hline \multirow{7}{*}{ 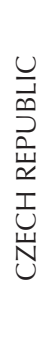 } & 2008 & 722 & 5 & 1918 & 13,2 & 7664 & 57 & 1594 & 11,8 & 8472 & 27 & 2587 & 8,2 \\
\hline & 2009 & 543 & 1 & 1486 & 2,7 & 6015 & 19 & 1211 & 3,8 & 6378 & 15 & 1929 & 4,5 \\
\hline & 2010 & 449 & 2 & 1348 & 6 & 5566 & 27 & 1197 & 5,8 & 6701 & 24 & 2042 & 7,3 \\
\hline & 2011 & 516 & 7 & 1528 & 20,7 & 3356 & 29 & 832 & 7,1 & 4058 & 24 & 1296 & 7,6 \\
\hline & 2012 & 744 & 5 & 2677 & 17,9 & 3034 & 22 & 751 & 5,4 & 3962 & 17 & 1316 & 5,6 \\
\hline & 2013 & 355 & 4 & 1336 & 15 & 3126 & 24 & 740 & 5,6 & 4515 & 18 & 1529 & 6 \\
\hline & 2014 & 334 & 10 & 1495 & 44,7 & 2756 & 28 & 680 & 6,9 & 4039 & 22 & 1344 & 7,3 \\
\hline \multirow{7}{*}{ 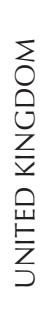 } & 2008 & 255 & 1 & 0 & 0 & 43830 & 48 & 1622 & 1,7 & 23945 & 16 & 1483 & 1 \\
\hline & 2009 & 290 & 3 & 5175 & 53,5 & 32359 & 41 & 1498 & 1,9 & 24478 & 10 & 1729 & 0,7 \\
\hline & 2010 & 224 & 1 & 7744 & 34,5 & 28372 & 50 & 1342 & 2,3 & 21732 & 12 & 1556 & 0,8 \\
\hline & 2011 & 282 & 6 & 0 & 0 & 28751 & 53 & 1343 & 2,4 & 18873 & 12 & 1315 & 0,8 \\
\hline & 2012 & 271 & 0 & 3126 & 0 & 22753 & 43 & 1060 & 2 & 17520 & 6 & 1185 & 0,4 \\
\hline & 2013 & 157 & 0 & 5934 & 0 & 24068 & 51 & 1123 & 2,3 & 2990 & 65 & 2045 & 4,4 \\
\hline & 2014 & 122 & 0 & 2725 & 0 & 24887 & 51 & 1144 & 2,3 & 29262 & 61 & 2059 & 4,2 \\
\hline \multirow{7}{*}{$\frac{\substack{Z \\
\frac{1}{2}}}{0}$} & 2008 & 1951 & 20 & 1140 & 11,6 & 10006 & 125 & 811 & 10,1 & 6040 & 80 & 673 & 8,9 \\
\hline & 2009 & 2266 & 36 & 1091 & 17,3 & 8215 & 118 & 1496 & 21,4 & 5375 & 38 & 1087 & 7,6 \\
\hline & 2010 & 2201 & 15 & 1702 & 11,6 & 8585 & 114 & 975 & 12,9 & 5993 & 63 & 837 & 8,8 \\
\hline & 2011 & 1930 & 18 & 1005 & 9,3 & 8755 & 99 & 664 & 7,5 & 6234 & 57 & 692 & 6,3 \\
\hline & 2012 & 1766 & 16 & 1379 & 12,5 & 7879 & 82 & 880 & 9,1 & 6163 & 61 & 841 & 8,3 \\
\hline & 2013 & 1571 & 8 & 1336 & 6,8 & 6244 & 71 & 557 & 6,3 & 5564 & 38 & 643 & 4,3 \\
\hline & 2014 & 1455 & 18 & 1324 & 16,3 & 5863 & 55 & 538 & 5 & 5537 & 42 & 640 & 4,8 \\
\hline \multirow{7}{*}{ 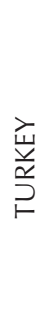 } & 2008 & 5728 & 30 & 11574 & 61 & 5574 & 397 & 449 & 32 & 3388 & 136 & 612 & 24 \\
\hline & 2009 & 8193 & 3 & 15763 & 6 & 6877 & 356 & 560 & 29 & 3911 & 49 & 669 & 8 \\
\hline & 2010 & 8150 & 92 & 16253 & 183 & 6437 & 475 & 443 & 32 & 4108 & 159 & 578 & 22 \\
\hline & 2011 & 9217 & 58 & 17840 & 112 & 7749 & 570 & 475 & 35 & 4142 & 229 & 524 & 29 \\
\hline & 2012 & 8828 & 20 & 17327 & 39 & 9209 & 256 & 514 & 14 & 4564 & 90 & 532 & 11 \\
\hline & 2013 & 11289 & 36 & 23177 & 73 & 26967 & 521 & 1457 & 28 & 15901 & 226 & 1790 & 25 \\
\hline & 2014 & 10026 & 335 & 24419 & 816 & 29699 & 501 & 1490 & 25 & 17074 & 211 & 2008 & 25 \\
\hline
\end{tabular}

Source: Eurostat Databeses and Turkish Social Security Institute Statistical Yearbooks

*2015 and 2016 statistics are not yet published in Turkey

Approximately 50,000 workers are employed in coal mining sector in Turkey. However, working conditions and protective measures against occupational accidents are still at a very low level. 91585 occupational accidents occurred and 821 workers died from 2003 to 2014. 955 workers died in 19 great mine accidents, including the Soma and Ermenek accidents in 2014, since 1983. One of the accidents occurred as landslide, two of them occurred as fire and the rest of them occurred as firedamp explosion. Since 1992, 12 of 13 great accidents occurred in the coal mines that are operated by private sector enterprises. 
According to the inspection results of Ministry of Labor and Social Security (2012), it is indicated that $7 \%, 23 \%$ and $83 \%$ of the mines don't have technical supervisor, explosives magazine and operation permit document, respectively, $43 \%$ of the mines don't measure gases regularly, $26 \%, 32 \%$ and $21 \%$ of the mines don't have occupational physician, occupational safety specialist and occupational health and safety committee, respectively. It is also indicated that coal mines don't have appropriate and adequate fortification, adequate ventilating system and escape routes. Expect big ones; mines generally don't have gas monitoring and distant signal systems and circuit breakers.

Construction is also referred as heavy industry due to the equipment used and the complexity of the total production processes. Construction industry uses and produces a wide variety of manufactured components in addition to basic construction materials. There is a major manpower requirement to maintain production in a construction site under hard working conditions with hazardous materials and machines.

Occupational accidents in construction sector are investigated in many different studies. Main reasons of these accidents are; inadequacy of trainings and personal protective equipment, not implementing "working at height" methods, not carrying out periodic maintenance and systematic environment measurements, working with subcontractors and inadequacy of inspections. In addition, managerial faults stand out during analyzing the reasons of accidents. It was observed that some major and minor occupational accidents were not recorded, reasons of these accidents were not analysed, risk assessments were not prepared well enough and precautions were not managed. In Turkey, $30 \%$ of the fatal accidents occur in construction sector every year and $30-40 \%$ of these accidents occur as "falling down from height". The risk of possible accidents in construction sites depend on five different reasons; falling from height, falling objects and being hit by objects, machinery and crane accidents, electric shock, and explosion. In Turkey, $90 \%$ of workers are subcontracted from third party companies in construction sector. Subcontractor system, which is commonly used in construction sector, limit the organization and to take measures for workers' health and safety (Rivara and Thompson, 2000; Tang et al., 2004; Arioglu and Arioglu, 1997; Ercan, 2010; Gurcanli, Bilir and Sevim, 2015; Gul et al., 2016).

Transportation/Shipping sector at which many of the fatal accidents occur as a result of vehicle accidents, takes the second place after construction sector in terms of accidents involving death in Turkey. According to the ILO, $50 \%$ of all goods transported in the world are hazardous materials. A large part of these materials are flammable, combustible and explosive. Transport and storage activities include accident risks for all industrial sectors. The risks of possible accidents in transportation and shipping sector depend on six main reasons; traffic accidents, falling from height, material overthrow or falls, forklift, crane and other machinery accidents, hazardous materials, electric shocks, and fires. The most important risk factor of accidents at work in the transport and storage is traffic accidents. Furthermore; forklifts, pallet trucks and lifting equipment such as mobile cranes, conveyors, hazardous chemicals, unsafe rack and stacking methods, unsuitable platform applications, improper electrical and ventilation systems, manual lifting and carrying works, workload, lack of education are among the leading reasons of occupational accidents. In maritime transport works; crane, forklift accidents and material strike or overthrow accidents are also widely encountered (Kristiansen, 2013; Islam and Hernandez, 2016; Liu and Moini, 2015; Yu et al., 2014).

\section{Statistical View of Accident Incidence Rates in Coal Mining, Construction and Transportation Sectors in Turkey and EU}

Total number of insured workers, the number of occupational accidents, fatal accidents and accident incidence rates in coal mining, construction and transportation/shipping industry are shown in Table 2. In 2013, 28.2\% per cent of non-fatal accidents, $58 \%$ of fatal accidents, and in 2014, 25.6\% of the total accidents, $65 \%$ of fatal accidents occur in these three sectors.s. Especially in terms of 2/3 of all deaths occurred in these three industries reveals the importance of preventive measures to be taken. 
According to the Eurostat data, in 2013 21\% of all work-related accidents in the European Union and $37 \%$ of all fatal accidents; in 2014 $20 \%$ of all work-related accidents and $38 \%$ of fatal accidents have occurred in these sectors. In 2013 and 2014, 1363 and 1377 fatal accidents occurred in these 3 sectors in EU. In 2014, as $76 \%$ of the deaths death occurred in these sectors in Turkey.

As shown in Table 2, accident incidence rate in the coal mining sector in Turkey is very high compared to EU countries. In some countries not to supply its energy needs from coal such as France and the United Kingdom, fatal and nonfatal accident rates are zero level. In Germany it is very low. In countries which coal production is currently continuing such as Spain and Poland, accident incident rates in is seen that at a very low level compared with Turkey. In Italy, no fatal accident occured between 2008-2014. In Turkey, the rate of accidents in the coal mining industry is much higher than all EU countries. Only in Spain in 2011 and 2013, incidence rates have occurred over Turkey. In addition, between the years 2008-2004 fatal accident rates are 5-6 times higher than in all other EU countries in the coal mining sector in Turkey. Especially in this period the incidence rates of fatal accidents in coal mining in Turkey significantly increased and after Soma disaster in 2014, it has reached 816 as a startling rate.

Whereas; incidence rates of work-related accidents in the construction and transport sector in Turkey seem low compared to both countries and throughout the European Union (see figure 1). But this is a misleading statistic for Turkey. Occupational accidents occurring in many sectors in Turkey are not reported to social security institutions. Statistics on accidents in the workplaces are not kept at a sufficient level. In addition, the rate of unregistered-uninsured employees by $35 \%$. Therefore, the accident incidence rates in these sectors must be also actually higher.

This situation can be observed more clearly when the incidence rates of fatal accidents investigated (see figure 2). Fatal accident incidence rate in the construction sector in Turkey is around 2-7 times more than in EU countries (see also table 2). In transport sector, the incidence rate of fatal accidents in Turkey is also 2 to 5 times more than in EU countries.

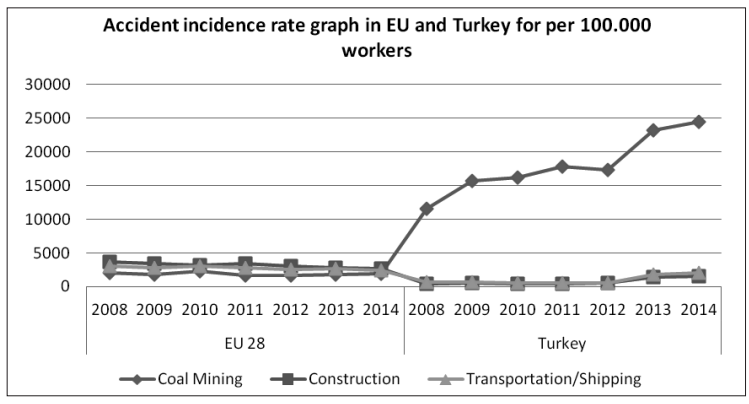

Figure 1. Occupational accident incidence rates in EU and Turkey

Slika 1. Stope učestalosti nesreća na radu u EU i Turskoj

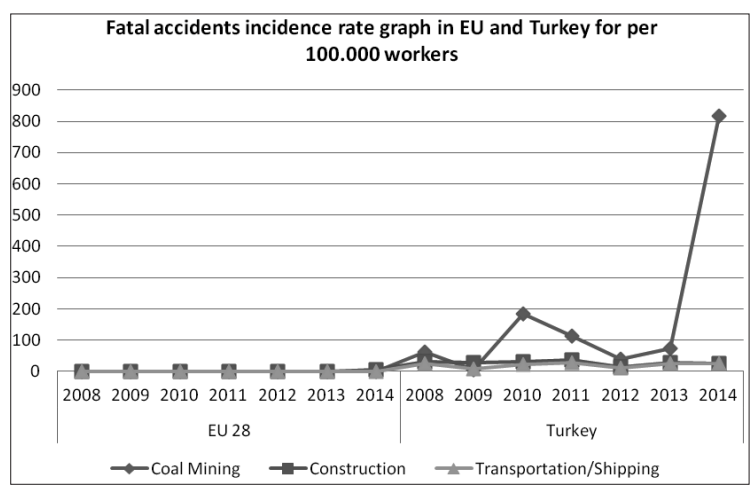

Figure 2. Fatal occupational accident incidence rates in EU and Turkey

Slika 2. Stope učestalosti nesreća na radu sa smrtnim posljedicama u EU i Turskoj

In addition, a significant increase is observed in all three sectors after 2012 in terms of the number of accidents and fatal accidents incidence rates in Turkey. Occupational Health and Safety Act came into force in 2012 in Turkey.

Furthermore, there has been a significant increase in the number of occupational accidents, and accident incidence rates after 2012 in Turkey in all three sectors. The most important reason for this increase is the fact that providing protective-preventive $\mathrm{OH} \& \mathrm{~S}$ services was made compulsory in workplaces as per the OH\&S Act that was introduced in 2012. The fines regarding the disclosure of occupational accidents to public authorities were increased, and accordingly the occupational accidents that occur in 
the workplaces were registered and disclosed to public authorities more often since $\mathrm{OH} \& \mathrm{~S}$ professionals began their work. Particularly in the construction and mining sectors, even though a large number of occupational accidents occur because of subcontracting practice rates that go as high as $90 \%$, too many unregistered employees, long working hours, and non-standard working ways; most of these accidents are not registered. It is estimated that the real number of occupational accidents in Turkey is 2-3 times more than the number of occupational accidents that have been registered so far.

Across the EU, a significant decline is observed in the occupational accident incidence rates in all three sectors. In the year 2014, there has been a $40 \%$ decrease in occupational accident incidence rates in coal mining, 30\% decrease in the construction sector, and $25 \%$ decrease in the transportation sector since 2008. Whereas the fatal accident rates seem to have dropped in the construction and transportation sectors, they have remained stable in coal mining. Construction sector has the highest fatality rate among all of the sectors.

\section{DISCUSSION}

Member states of the European Union have taken on a "preventive approach" in health and safety, with the extensive regulations they made in accordance with the "Framework Directive 89/391" which was adopted by the EU in 1989. This approach has yielded results in the recent years, having triggered gradual decrease in occupational accident numbers in EU countries. The modern approach in health and safety does not only comprise of legislations, inspection and sanction; but it is primarily based on determining the risks in the workplace, taking precautions and making inspections through organizations at the workplace level.

Turkey is currently a candidate country for European Union accession. Its negotiation process has been continuing since 2003. In Turkey, extensive legal and institutional regulations regarding health and safety have been made as part of adaptation to the European Union. A "preventive approach" that was based on risk assessment has been adopted in order to comply with the ILO convention no. 161, favored in 2004, and the Framework Directive 89/391 of the European Union. Within this framework; legislative regulations were made on risk assessment, preventive $\mathrm{OH} \& \mathrm{~S}$ services, safety specialists, OH\&S committees, employee representatives and training. Preparing health and safety plans in constructions and mines was made compulsory. Penalties were increased. A separate Act was passed under the name of 2012 OHS Act, and new directives were prepared. Nevertheless, occupational accidents did not decrease during the 4 year period. Major accidents occurred particularly in coal mines and on construction sites, where tens of workers lost their lives.

Existing problems and evaluations in Turkey may be listed under these titles:

1. Despite the extensive legislative regulations, the number and rates of labour inspections are inadequate. As a matter of fact, among these three sectors that cause the most fatality; while all of the mines were inspected in the year 2013, the inspection rate was $5 \%$ in constructions and down to $3 \%$ in the transportation sector. The number of inspectors working in the Ministry of Labor and its organizational structure are inadequate.

2. Many studies indicated that there are serious safety deficiencies which restrict a safe production progress in coal mines in Turkey. Mining enterprises in Turkey do not comply with safety rules adequately. There has been a significant increase in accidents that occur in mines as mining basins were turned over to subcontractors by leasing.

3. Approximately 500 fatal occupational accidents occur every year in the construction sector. Each year, 30-40\% of overall fatalities occur in the construction sector. Subcontraction rate is $90 \%$, and unregistered and illegal immigrants are employed. Working hours are flexible and long. The workers work under time pressure and heavy working conditions. Workers are poorly educated and the employers lack sensitivity towards occupational safety matters. 
4. Most of the fatal accidents in the transportation sector occur in the form of traffic accidents. Traffic safety and the culture of abiding by the traffic rules are extremely poor. Hence, more than 5 thousand people are killed in traffic accidents each year in Turkey. Inspections and penalties fail to suffice.

5. Separate from legal arrangements, action plans must be prepared for each of the three sectors. Practices must be determined and followed within the frame of these action plans.

6. The competition conditions in all three sectors impose fast-paced working under time pressure. It is crucial that employers are inspected and made more sensitive towards this issue.

7. In all of the sectors in Turkey, flexible working forms such as part-time working and working within time limits have become increasingly widespread. Workers work long hours, under poor conditions for a low salary. Additionally, cost-cutting concerns that have arisen due to subcontracting in the construction and mining sectors also cause occupational safety precautions to be neglected.

8. Working times of safety specialists are not adequate. There is no obligation in workplaces that employ less than 250 workers and that fall under the very high-hazard classification to have a full-time specialist on site. In accordance with hazard classification and employee count, workplaces may get part-time service from external health and safety services. However, such external resources provide low quality services.

9. Production equipment used in mines and some construction sites are outdated, defective or have been neglected. Many fatal occupational accidents occur due to the machines, lifting devices and hand tools used in production. Even though the legislative regulations concerning this issue have been improved, still not enough care is taken regarding the periodic maintenance within the $\mathrm{OH} \& \mathrm{~S}$ management systems. Public authorities must also monitor whether or not periodical maintenance is carried out regularly during inspections.
10. The protective equipment provided to the workers are insufficient, defective or unfit. The trainings that workers receive on the utilization of this equipment are inadequate. The efficiency of occupational safety trainings provided in workplaces must be evaluated and continuously improved.

11. Safety issues is not regarded as part of system awareness, and occupational safety is perceived to be the responsibility of safety professionals. $\mathrm{OH} \& \mathrm{~S}$ management system practices, $\mathrm{OH} \& \mathrm{~S}$ organizations and awareness raising trainings have not reached a sufficient level. Safety works particularly in the mining, construction and transportation sectors must be practiced within the scope of management systems.

\section{Conflicts of interest}

The authors declare no conflicts of interests.

\section{REFERENCES}

Arioglu, E., Arioglu, N.: Statistical evaluation and minimizing of occupational accidents in the Turkish construction sector, Concrete-Prefabrication Magazine, 1997., 2, 16-21. (in Turkish).

Coggon, D., Rose, G., Barker, D.J.: Quantifying diseases in populations. Epidemiology for the uninitiated, 4th ed, BMJ, 1997.

Dembe, A.E., Erickson, J.B., Delbos, R.G., Banks S.M.: The impact of overtime and long work hours on occupational injuries and illnesses: new evidence from the United State, J Occup Environ Med, 2005., 62, 588-97. doi: http://dx.doi.org/10.1136/oem.2004.016667

Dunn, O.J., Clark, V.A.: Basic statistics: a primer for the biomedical sciences, 4th ed, Hoboken, NJ: John Wiley \& Sons, 2009.

Ercan, A.: Evaluation of the health and safety of workers in the construction sector in Turkey, Journal of Polytechnic, 13, 2010, 1, 49-51.

Grayson, R.L. Safety productivity and other factors in US underground coal mines, Mining Engineering, 53, 2001, 8, 40-44. 
Groves, W.A., Kecojevic, V.J., Komljenovic, D.: Analysis of fatalities and injuries involving mining equipment, J Safety Res, 38, 2007, 4, 461-70. doi: http://dx.doi.org/10.1016/j. jsr.2007.03.011

Gül, M., Güneri, A.F., Yılmaz, F., Çelebi, O.: Analysis of the relation between the characteristics of workers and occupational accidents using data mining, The Turkish Journal of Occupational/Environmental Medicine and Safety, 1, 2016, 4, 102-18.

Gurcanli, G.E., Bilir, S., Sevim, M.: Activity based risk assessment and safety cost estimation for residential building construction projects, Safety Science, 80, 2015, 1, 1-12. doi: http:// dx.doi.org/10.1016/j.ssci.2015.07.002

Hull, P.B., Leigh, J., Driscoll, R.T., Mandryk, J.: Factors associated with occupational injury severity in the New South Wales underground coal mining industry, Safety Science, 21, 1996, 1, 191-204. doi: http://dx.doi.org/10.1016/j. aap.2012.07.002

Islam, M.B., Hernandez, H.: Fatality rates for crashes involving heavy vehicles on highways: A random parameter tobit regression approach, Journal of Transportation Safety \& Security, 8, 2016, 3, 247-65. doi: http://dx.doi.org/10.1080 /19439962.2015.1027071

Kristiansen, S.: Maritime transportation safety management and risk analysis, NY, Routledge, 2013.
Last, J,M.: A dictionary of epidemiology, 4th ed., New York, Oxford University Press, 2001.

Liu, R., Moini, N.: Benchmarking transportation safety performance via Shift-Share approaches, Journal of Transportation Safety \& Security, 7, 2015, 2, 124-37. doi: http://dx.doi. org/10.1080/19439962.2014.940478

Pappas, D.M., Mark, C., Dolinar, D.R., Bhatt, S.K.: Profile of ground fall accidents in underground coal mines, Mining Engineering, 9, 2003, 1, 65-71.

Rivara, F.P., Thompson, D.C.: Prevention of falls in the construction industry: evidence for program effectiveness, Am J Prev Med, 18, 2000, 4, 23-26. PMID: 10793277

Tang, S.L., Ying, K.C., Chan, W.Y., Chan, Y.L.: Impact of social safety investments social costs of construction accidents, Journal of Construction Engineering and Management, 22, 2004, 9, 937-46. doi: http://dx.doi.org/10.1080/ 0144619042000226315

Turkkan, A., Pala. K.: Trends in occupational injuries and fatality in Turkey, JOSE, 22, 2016, 4, 457-62. doi: http://dx.doi.org/10.1080/1080354 8.2016 .1153224

Yu, J., Pande, A., Nezamuddin, N., Dixit, V., Edwards, F.: Routing Strategies for Emergency Management Decision Support Systems During Evacuation, Journal of Transportation Safety \& Security, 6, 2014, 3, 257-73. doi: http://dx.doi. org/10.1080/19439962.2013.863258 


\section{EVALUACIJA SIGURNOSTI NA RADU U GRAĐEVINARSTVU, RUDARSTVU I PRIJEVOZU U TURSKOJ}

SAŽETAK: Proizvodni procesi u građevinarstvu, rudarstvu i prijevozu svuda u svijetu visoko su rizični sektori. U Turskoj se 2014. godine 25,6 \% svih nesreća i 65 \% nesreća sa smrtnim posljedicama dogodio upravo u tim sektorima. Prema podacima Eurostata, godine 2014. ti su sektori u EU bilježili 20 \% ukupnih nesreća na radu, a $38 \%$ bilo je sa smrtnim posljedicama. Stopa smrtnosti u Turskoj vrlo je visoka u usporedbi s EU. U Turskoj, navedeni sektori vrlo su visoko rizični, i to zbog nepravilnosti u proizvodnim procesima, zastarjele tehnologije, loših uvjeta rada i velikog broja radnika. Proizvodni strojevi su stari, a zaštita na radu neprimjerena. Najveći problem je u građevinarstvu, i to zbog raširenosti rada na crno i prepuštanja poslova podizvođačima. Inspekcija rada ne radi dovoljno dobro. Nadalje, u pristupnom procesu za ulazak u EU legislativa povezana sa zaštitom zdravlja i sigurnost na radu nije se razvijala kako treba. Uvedena je nova regulativa u vezi sa zaštitom i prevencijom, procjenom rizika na radu te informiranjem i edukacijom radnika. Unatoč tome, stopa nesreća na radu nije opala do zadovoljavajuće razine. Članak donosi komparativnu i statističku analizu nesreća u rudarstvu, građevinarstvu i prijevozu u Turskoj i EU. Korišteni su službeni statistički podaci EU-a i Turske. Kako bi se nesreće spriječile, potrebno je donijeti akcijske planove za svaki od ovih sektora. Praksa mora strogo slijediti odredbe donesenih akcijskih planova.

Ključne riječi: nesreće, sprečavanje nesreća, zdravlje ljudi, sigurnost, Turska

Pregledni rad

Primljeno: 6.3.2017.

Prihvaćeno: 20.10 .2017 